\title{
Fertilizer for Sweet Pepper Under Drip Irrigation in an Oxisol in Northwestern Puerto Rico ${ }^{1,2}$
}

\author{
J. C. W. Keng, T. W. Scott and M. A. Lugo-López ${ }^{3}$
}

\begin{abstract}
A drip irrigation system using porous plastic tubing was designed to study operational techniques of drip irrigation and fertilizer management in a highly weathered, leached, relatively low fertility, acid Oxisol. Sweet pepper (Capsicum annuum) was the test crop. All plots received an initial broadcast application of a 10-4.4-8.3 N-P-K fertilizer at the rate of $80 \mathrm{~kg} / \mathrm{ha}$. The experiment followed a randomized complete block layout with 4 treatments and 6 replications. The treatments were as follows: 1) $\mathbf{N}$ and $\mathrm{K}$ injected into the drip system, P banded; 2) banded N, P and K with drip irrigation; 3) broadcast $\mathrm{N}, \mathrm{P}$ and $\mathrm{K}$ with drip irrigation; and 4) control-drip irrigation, no $\mathrm{N}, \mathrm{P}$ and $\mathrm{K}$ other than the initial overall broadcast application. All treatments, except the control, received a total of $56.8 \mathrm{~g}$ of a 10-10-10 fertilizer per plant and all were uniformly drip irrigated according to pan evaporation data. Two crops were grown: one in the dry season and one in wet season. Yields were significantly different among all treatments for the dry season crop, with a high of $82.62 \mathrm{~kg} /$ ha for the treatments where $\mathrm{N}$ and $\mathrm{K}$ were injected into the drip system and a low of $31.54 \mathrm{~kg} / \mathrm{ha}$ for the control. For the wet season crop, no significant yield differences were found when fertilizer was injected into the drip system and when banded, but both these treatments were superior in yield to that of broadcast. These three treatments were superior to the control, with more than $100 \%$ increase. Drip irrigation is a promising alternative to currently used water-nutrient management methods for Oxisols in the wet-dry tropics.
\end{abstract}

\section{INTRODUCTION}

The usually high rainfall intensities prevailing during the wet season in most humid tropical areas demand special management of plant nutrients for intensive production of most food crops. The hydraulic properties of Oxisols, according to Wolf and Drosdoff (9), include a relatively high permeability and low available water-holding capacity. Since periodic droughts occur even during the rainy season, supplemental irrigation is required in most areas of the tropics for stable crop production.

Grobbelaar and Lourens (2), Isobe (3), Lindsey and New (6), Rauschkolb et al. (8) reported the results of applying fertilizers through a drip irrigation system. However, work on the application of drip irrigation in

\footnotetext{
${ }^{1}$ Manuscript submitted to Editorial Board January 15, 1980.

${ }^{2}$ Joint contribution from the Department of Agronomy, Cornell University, Ithaca, N.Y., the Agricultural Experiment Station, University of Puerto Rico, Mayagüez Campus, Río Piedras, P.R., and the Land Resource Research Institute, Ottawa, Canada. This study was part of the investigations supported by U.S. AID under research contract ta-c-1104.

${ }^{3}$ Former Graduate Student at Cornell Univ., now Research Soil Physicist, Land Resource Research Institute, Ottawa, Canada; Professor of Soil Science, Cornell University, and Professor and Soil Scientist (ret.), University of Puerto Rico, now Consultant Cornell University, respectively. Dr. G. Levine was an adviser; Angel Serrano helped in the field experiments; E.I. DuPont Co. furnished the experimental porous tubes.
} 
tropical areas, especially on Oxisols, has been very limited. There is no information in the literature with respect to combined water and nutrient management on Oxisols using drip irrigation techniques, except for the work of Keng et al. (5).

Since Oxisols have low nutrient and available water holding capacities, drip irrigation can help to maintain a favorable soil moisture and nutrient level for plant growth. According to Goldberg et al. (1), drip irrigation also encourages root development in the surface soil. This would be advantageous in Oxisols where crop rooting in the subsoil may be restricted by A1 toxicity.

The purpose of this study was to evaluate methods for applying $\mathrm{N}, \mathrm{P}$ and $\mathrm{K}$ under drip irrigation, a concept for intensive cultivation of Oxisols in the tropics.

\section{MATERIALS AND METHODS}

The experiment was conducted at the Isabela Substation farm in northwestern Puerto Rico. Average annual rainfall is about $170 \mathrm{~cm}$. Much of the rainfall may not be available to crops, however, because of the erratic distribution pattern and the low available water-holding capacity of the soil. The soil at the experimental site is classified according to the U.S. Soil Taxonomy System, as Coto, Tropeptic Haplorthox, clayey, kaolinitic, isohyperthermic (7). It is a highly weathered, leached, acid soil of relatively low fertility.

An area, $40 \times 60 \mathrm{~m}$, with a slope of less than $2 \%$ from south to north, was selected as the experimental site. Three different methods were used to apply the same total quantity of $\mathrm{N}$ and $\mathrm{K}$ (N:224 kg/ha; K:186.4 kg/ ha) throughout each growing season. Four treatments, including a check, were arranged in a randomized complete block design with six replicates. Each block had two $1.7 \times 10 \mathrm{~m}$ beds. Porous plastic irrigation tubes (Viaflo tube, E.I. Dupont De Nemours, Wilmington, Delaware, U.S.A.) ${ }^{4}$ were laid along the central line of each bed to deliver water and/or fertilizer solutions to the plants.

To protect the tubes from the tropical sun as well as to make field operations easier, all the delivery tubes were buried about $5 \mathrm{~cm}$ below the soil surface. Treatments were given separately by using two different branches of the irrigation head unit. A check valve was used to avoid contamination of the irrigation water.

A pressure system was designed to apply $\mathrm{N}$ and $\mathrm{K}$ fertilizers into the drip system. A compressed air tank was connected to the homemade fertilizer injector. Operational pressure for this system was set at $1.4 \mathrm{~kg} /$ $\mathrm{cm}^{2}\left(20 \mathrm{lb} / \mathrm{in}^{2}\right)$.

\footnotetext{
${ }^{4}$ Trade names are used for identification purposes and do not imply preference for this material.
} 
Twelve tensiometers were randomly installed in the experimental area at depths of 15 and $30 \mathrm{~cm}$. Irrigation frequency and duration were manually controlled on the basis of the soil matrix potential and/or previous day's pan evaporation. On non-rainy days, an irrigation duration of $2 \mathrm{~h} /$ day, or $1000 \mathrm{ml}$ of irrigation water/plant/day was sufficient during the wet season crop. A longer irrigation time of about 3-4 h/day, or 1500$1750 \mathrm{ml}$ irrigation water/plant/day, depending on weather conditions, was needed for the dry season crop. Tensiometer readings indicated a uniform distribution of irrigation water throughout the drip system, and the soil moisture content in the root zone was maintained at field capacity throughout the growing season.

Two successive crops of sweet pepper (Capsicum annuum), cv. Blanco del País, (a 20-week growth period for each crop in each season) were used as the test crop on the same site. Pepper was chosen as the indicator crop because of its long growing season and its sensitive response to soil nutrient supply. Thirty seedlings were transferred from the greenhouse to the field 35 days after seeding, and transplanted with a plant population equivalent to 13,340 plants/ha. They were planted in two rows per each bed, $15 \mathrm{~cm}$ from each side of the irrigation tubing in a triangular pattern.

Since the experimental site had been fallow for at least 5 years, only 80 $\mathrm{kg} / \mathrm{ha}$ of $10-4.4-8.3 \mathrm{~N}-\mathrm{P}-\mathrm{K}$ fertilizer was broadcast over the entire area to aid in establishment of the crop.

The four treatments in the experiment were as follows: Treatment 1.$\mathrm{N}$ and $\mathrm{K}$ injected into the drip system; $\mathrm{P}$, banded.

Urea and muriate of potash were dissolved in water and injected into the drip system with a positive pressure. In total, $224.6 \mathrm{~kg} / \mathrm{ha}$ of $\mathrm{N}$ and $186.4 \mathrm{~kg} / \mathrm{ha}$ of $\mathrm{K}$ were applied to the soil during each growing season. The injections were carried out weekly, and the dosage of each injection was adjusted to meet the plant needs during the various growth periods.

Triple superphosphate (TSP) was banded at $7 \mathrm{~cm}$ along each side of the irrigation tubes. Two applications per growing season were used: 49.5 $\mathrm{kg} / \mathrm{ha}$ was banded before transplanting and an additional $49.5 \mathrm{~kg} / \mathrm{ha}$ was sidedressed after the third picking. $\mathrm{P}$ fertilizer is not recommended for application with drip systems because of its low mobility in Oxisols (4). Treatment 2.-Banded application of fertilizer with drip irrigation.

A base fertilizer at the rate of $112.3 \mathrm{~kg} / \mathrm{ha}$ of a 10-4.4-8.3 was banded along both sides of the irrigation tubing, $7-10 \mathrm{~cm}$ deep and $7 \mathrm{~cm}$ to the side of the plants before transplanting; and an additional $112.3 \mathrm{~kg} / \mathrm{ha}$ of the same fertilizer was sidedressed after the third picking.

Treatment 3.-Broadcast fertilizer application with drip irrigation.

A 10-4.4-8.3 fertilizer was broadcast in the center 1-meter-wide strip of each bed. The amount of fertilizer and time of application were identical to those of treatment 2 . 
Treatment 4.-Check. No additional fertilizer was applied to the check plots after the $80 \mathrm{~kg} / \mathrm{ha}$ initial application of 10-4.4-8.3 fertilizer broadcast over the entire experimental area.

For all treatments, base fertilizer was applied 4 days before transplanting. A side-dressing was made after the third picking, i.e., 12 weeks after transplanting. Treatment 1 received liquid $\mathrm{N}$ and $\mathrm{K}$ fertilizer weekly. The total $224.6 \mathrm{~kg} / \mathrm{ha}$ of $\mathrm{N}$ and $186.4 \mathrm{~kg} / \mathrm{ha}$ of $\mathrm{K}$ were used in this treatment for each growth period. During the middle 10 weeks of the growth period, $7.5 \mathrm{~kg} / \mathrm{ha}$ of $\mathrm{N}$ and $6.2 \mathrm{~kg} / \mathrm{ha}$ of $\mathrm{K}$ were applied in each fertilization to meet the plant's needs.

Diphenamid (Enide 50W), a pre-emergent herbicide, was sprayed on all the plots 3 days after transplanting. Insecticide (Lannate 90S) and fungicide (Dithane M-45) were sprayed biweekly or more often if necessary to control insects and foliar diseases.

TABLE 1.-Yield of sweet peppers from the wet and dry season crops

\begin{tabular}{llcccc}
\hline & \multicolumn{5}{c}{ Yield } \\
\cline { 2 - 6 } Season & \multicolumn{5}{c}{ Treatments $^{1}$} \\
\cline { 2 - 6 } & \multicolumn{1}{c}{2} & \multicolumn{5}{c}{4} & Mean \\
\hline & & & & \\
Dry & $82.62 \mathrm{a}^{2}$ & $73.00 \mathrm{~b}$ & $62.90 \mathrm{c}$ & $31.54 \mathrm{~d}$ & 62.51 \\
Wet & $86.71 \mathrm{a}$ & $89.59 \mathrm{a}$ & $79.63 \mathrm{~b}$ & $37.04 \mathrm{c}$ & 73.24 \\
Mean & 84.66 & 81.30 & 71.26 & 34.29 & \\
\hline
\end{tabular}

${ }^{1}$ Treatments: $\mathrm{I}=\mathrm{N}$ and $\mathrm{K}$ injected into the drip system, $\mathrm{P}$ banded. 2 = Banded application of fertilizer with drip irrigation. 3 = Broadcast fertilizer application with drip irrigation. 4 = Check, no additional fertilizer applied other than the $80 \mathrm{~kg} / \mathrm{ha}$ initial application, drip irrigation.

${ }^{2}$ Means within a season followed by a different letter significantly differ at the $5 \%$ probability level.

Puerto Rico pepper mosaic virus, usually spread by aphids, appeared in the second crop after transplanting, although only a few of the affected plants eventually wilted and died. In most of the affected plants, there were fewer flowers and fruits than in the non-affected, and plants suffered a setback in growth. After an increase in the number of insecticide sprays, the aphid population was controlled, and the virus spread less. Mature fruits were selected and hand-harvested biweekly for yield data.

\section{RESULTS AND DISCUSSIONS}

Analysis of fruit yields indicates significant differences among treatments 1, 2, 3 and 4 during the dry season, and also treatments 1, 3 and 4 for the wet season (table 1). For the wet season crop, no statistically significant difference (95\% level) was found between treatments 1 and 2 . Yield from the broadcast fertilizer treatment was $15.8 \%$ lower than that 
from treatment 1 , where $\mathrm{N}$ and $\mathrm{K}$ were injected into the drip system, and 12.3\% lower than the banded fertilizer treatment (table 1).

In the first crop (wet season), the banded fertilizer treatment resulted in the highest yield at the first three harvests. Increasing yields with maturity leveled off in treatments 2,3 and 4 after the third picking, and increased again after the fourth picking. Yields in treatment 1 increased between the third and fourth pickings (when plants were 4 months old), and exceeded the other three treatments in yields at the last two pickings. A drop in yield was first noticed in the check plots when plants were 5 months old. The other three treatments also showed decreasing yields 2 weeks later.

Favorable winter temperature caused a faster growth rate in the early stage after transplanting the second crop. This crop (dry season) later suffered from aphid attacks and a spreading of the Puerto Rico pepper mosaic virus, which adversely affected yields. Treatment 1 had the highest yield in each picking followed in order by the banded fertilizer treatment, broadcast fertilizer treatment, and the check plots.

An understanding of the nutrient distribution, and root system development, would indicate that the fertilizer injected into the drip system and the banded fertilizer methods are superior to the broadcast method in Oxisols. In the analysis of the distribution of yield data with time, some interesting points are found: 1) The increasing yields of treatments 2, 3 and 4 slow down after the third picking, reflecting the decreasing nutrient supplying power of the soil. The sidedressed fertilizer results in yield gains in the fifth picking; 2) In the fertilizer-injected treatment, because of the continuous nutrient supply, the yield increased smoothly without interruption; 3) In the first crop, the yield from the first three pickings of the fertilizer-injected treatment were lower than those from the banded fertilizer treatment. This may have been due to insufficient lateral movement of irrigation water with the result that the nutrient solution applied with the drip system could not reach the young plants' root systems; 4) In the second crop, the residual effect of the previous season's fertilization provided the initial nutrients for early crop growth; therefore, yields from plots of the fertilizer-injected treatment were higher than the others throughout the season.

\section{RESUMEN}

Se diseñó un sistema, utilizando tubos de material plástico, para estudiar el uso de la técnica de riego por goteo y del suministro de abonos en un Oxisol muy intemperizado, lixiviado, de fertilidad relativamente baja y ácido. Se utilizó el pimiento como cosecha indicadora. Todas las parcelas recibieron una aplicación inicial a voleo, de un abono 10-4.4-8.3 a razón de $80 \mathrm{~kg} / \mathrm{ha}$. Se utilizó un diseño de bloques- 
completos aleatorios con cuatro tratamientos y seis repeticiones. Los tratamientos fueron como sigue: $1 . \mathrm{N}$ y $\mathrm{K}$ inyectados en el sistema de riego por goteo, $\mathrm{P}$ aplicado en franjas; 2 . N, P y K aplicado en franjas; 3. N, P y K a voleo; y 4. Testigo- $\sin \mathrm{N}, \mathrm{P}, \mathrm{K}$ fuera del aplicado inicialmente a voleo en todas las parcelas. En todos los tratamientos, excepto el control, se aplicaron $56.8 \mathrm{~g} /$ planta de un abono 10-10-10 y todos recibieron riego por goteo. Se hicieron dos siembras: una en la temporada de sequía y otra en la lluviosa. Los rendimientos de pimiento fueron significativamente diferentes entre todos los tratamientos en la temporada de sequía. En la temporada lluviosa las diferencias en rendimiento no fueron significativas entre el tratamiento en que se inyectó $\mathrm{N}$ y $\mathrm{K}$ en el sistema de riego y el tratamiento en que se aplicaron estos nutrimentos en franjas. Sin embargo, se obtuvieron rendimientos significativamente más altos con estos dos tratamientos que con el que se aplicó el abono a voleo. Estos tres tratamientos fueron superiores al testigo. El sistema de riego por goteo parece ser un método prometedor para el uso y suministro de agua y nutrimentos en los Oxisols de las regiones tropicales.

\section{LITERATURE CITED}

1. Goldberg, S. D., Rinot, M., and Karu, N., 1971. Effect of trickly irrigation intervals on distribution and utilization of soil moisture in a vineyard, Soil Sci. Soc. Am. Proc. 35: $127-30$.

2. Grobbelaar, H. L. and Lourens, F., 1974. Fertilizer application with drip irrigation, Proc. 2nd Int. Drip Irrig. Congr. (San Diego, CA), pp. $\approx i-5$.

3. Isobe, M., 1974. Investigations in sugarcane fertilization by drip irrigation in Hawaii, Proc. 2nd Int. Drip. Irrig. Cong. (San Diego, CA) pp. 405-10.

4. Keng, J. C. W., 1978. Water and nutrient management with drip irrigation in highly weathered soils of the tropics, Ph.D thesis, Cornell Univ., Ithaca, N.Y.

5. - - Scott, T. W., and Lugo-López, M. A., 1979. Fertilizer management with drip irrigation in an Oxisol, Agron. J. 71(b): 971-80.

6. Lindsey, K. E. and New, L. L., 1974. Application of fertilizer materials through drip irrigation systems in West Texas, Proc. 2nd Int. Drip Irrig. Cong. (San Diego, CA), pp. $400-4$.

7. Lugo-López, M. A. and Rivera, L. H., 1978. Updated taxonomic classification of the soils of Puerto Rico, Agri. Exp. Stn. Bull. 285. Univ. P.R.

8. Rauschholb, R. S., Rolston, D. E., Miller, R. J., Carlton, A. B., and Burau, R. G., 1976. Phosphorus fertilization with drip irrigation, Soil Sci. Soc. Am. Proc. 40: 68-72.

9. Wolf, J. M. and Drosdoff, M., 1976. Soil-water studies in Oxisols and Ultisols of Puerto Rico: II. Moisture retention and availability, J. Agri. Univ. P.R. 60 (3): 386-94. 